\title{
Religious education for ecological sustainability: an initial reality check using the example of everyday decision-making
}

\author{
Stefan Altmeyer ${ }^{1}$ (D)
}

Accepted: 8 December 2020 / Published online: 23 January 2021

(c) The Author(s) 2021

\begin{abstract}
There is a widely accepted consensus that religious education, together with all other school subjects, should contribute to the goals of education for sustainable development. As a result, theoretical models have been developed to profile what the specific contributions of religious education might be. However, the question whether religious education can achieve the intended goals has not yet been researched in more detail. More fundamentally, to be able to formulate realistic goals involves the clarification of students' predispositions. In the light of these questions, the author focuses on an ecological sustainability dilemma, the so-called poplar dilemma, and asks how students react to this conflictive situation and what roles religious orientations play in their responses. Analysis of the responses of a sample of more than 1100,14- to 16-year-old students at secondary schools in Germany and Austria led to the conclusion that over-reaching, action-changing environmental sustainability goals are probably beyond the reach of religious education as a single subject. Nevertheless, it becomes clear that ecological issues are regarded by many as religious and spiritual questions and can therefore be addressed in a focused way through religious education. The idea of religious stewardship, which implies taking responsibility and addresses both religious and non-religious students, could be particularly promising. Religious education could develop a characteristic profile as an area in which translation between different motivations for engaging in religious stewardship occurs, and where commitments to taking responsibility are sought.
\end{abstract}

Keywords Education for sustainable development · Religious education · Decisionmaking $\cdot$ Empirical research $\cdot$ Environmental education $\cdot$ Dilemma

For Reinhold Boschki, academic mentor and friend, on the occasion of his sixtieth birthday in May 2021.

Stefan Altmeyer

s.altmeyer@uni-mainz.de

1 Department of Religious Education, Faculty of Catholic Theology, Johannes GutenbergUniversity, 55099 Mainz, Germany 


\section{Introduction}

No one can claim that the call for education to decisively contribute to the goals of sustainable development in a consistent and interdisciplinary manner is a novel one. As early as 1992, Agenda 21 (UNCED 1992) consistently linked the issue of ecological sustainability with education, and through the World Decade of Education for Sustainable Development, the United Nations committed itself to the vision of a world "where everyone has the opportunity to benefit from education and learn the values, behaviour and lifestyles required for a sustainable future and for positive societal transformation" (UNESCO 2006, p. 24). These objectives are still valid and have again been reaffirmed in the 2030 Agenda (United Nations 2015). Nevertheless, recent developments and the increasingly impatient protests of young climate activists emphasise that the implementation of sustainability goals in educational policies and programmes has so far only begun. Unfortunately, religious education appears not to be an exception to this sobering rule. In a remarkable book, the German religious education scholar Bederna (2020) recently wrote:

Religious education for sustainable development is more than ethical learning with a specific subject. The contemporary diagnosis of fundamental non-sustainability is a challenge to Christian speech on God. [...] Those beliefs which claim a relationship between God and the world and within it to humankind must be reformulated and translated in this light. [...] The task, however, is too big. It is urgent and everything is at stake: the core problem of the future and core ideas of theology. (pp. 17-20, own translations)

There is certainly no lack of good arguments that religious education-with its diverse manifestations and organisational forms worldwide ${ }^{1}$ - could play an important role in transitioning towards sustainability, nor is there a shortage of normative calls to consistently put this contribution into practice. Although Chamberlain (2000) noted an alarming "absence of ecological insights" (p. 134) in religious education discourse 20 years ago, and Martin (2015) still criticised a veritable gap "between our appreciation of the reality of ecological devastation and our work in religious education" (p. 34) 5 years ago, a "significant uptick of activity" (Tomlinson 2019, p. 186) has recently emerged. In the context of Catholic religious education, the impulse of the encyclical Laudato Si', in which Pope Francis (2015) clearly called for "ecological conversion" (No. 217), was probably particularly important for this development. The proposals for integrating "ecology as a constituent dimension of Christian education" (Tomlinson 2019, p. 187) cover a wide range of cognitive, ethical and spiritual aspects. We can differentiate between two approaches: The first, faith-formation concept aims to teach people to be religious in a way that helps them with the "cultivation of ecologically grounded faith" (Ayres 2017, p. 64). Here, the personal involvement in religious narratives, the orientation towards spiritual models and the cultivation of virtues play a central role (Tomlinson 2019; Bouma-Prediger 2016; Fleischer and DeMoor 2015; Ayres 2014; Effiong 2011; Price 2008; Dunn 1990). The second, more reflective approach, focuses on theological implications and interpretations of the sustainability crisis and aims to stimulate critical judgment as a basis for conscious commitment.

\footnotetext{
${ }^{1}$ I am writing this paper against the background of the model of denominational religious education as a compulsory subject at state schools, as is characteristic for Germany and Austria. This context certainly influences my reflections and arguments. Nevertheless, I believe that both the topic and the results of the presented research are also relevant in numerous global contexts.
} 
The focus is on the "complicated and big questions that can inspire truly critical thinking" (O'Brien 2014, p. 194), from the theology of creation and cosmology and the question of guilt and hope, to finiteness and justice (Bederna 2020; Grelle 2018; Hoven 2015; Horrell and Davis 2014; Chamberlain 2000; Bratton 1990; Hill 1990). Most aspects are grouped together in the anthropological challenge of "rethinking what it means to be human in relationship to Nature" (Martin 2015, p. 25). ${ }^{2}$

However convincing the proposals may be in detail, and however fully supportable the demands made, there is a type of surplus of normativity evident in publications within both approaches, which may also hinder practical implementation. I would like to illustrate this by taking Bederna's above-mentioned position as an example. In her book, she argues that sustainability is not an important and ultimately contingent educational topic, but forms a universal ethical principle. By structural analogy to Kant's categorical imperative, she defines the principle of sustainability as a moral obligation for all individuals to live "in such a way that what is done with 'nature' could always be done by anyone, anywhere, everywhere" (Bederna 2020, p. 103). This "ecological imperative" (p. 104) is then no longer based solely on the acute ecological crisis and its pressure to act, but posits that the preservation of the basis of life for future generations is a universal obligation. This arises from the personal realisation of freedom, which always has to include the freedom of others, including future generations. In the sense of an emancipatory understanding of education-meaning that education at its heart should empower (young) people to realise their own freedom-sustainability is thus a mandatory constituent of education for all school subjects. Religious education could contribute to this in a specific way by

[...] interrupting the flow of the normal and non-sustainable and by introducing and exploring a different world view - from the encounter with creation as a vision of sustainability, as common home and as a gift in which God gives himself, to the confrontation with forms of sufficiency and poverty as freedom [for example in the spirituality of mendicant orders] [...] or the reflection of guilt and the enabling of conversion. (p. 272)

Religious education for sustainable development, as Bederna calls it (cf. also Effiong 2011, p. 152), is therefore not required for reasons of objective norms (for example, according to the motto: 'Christians should live in a sustainable way!'), but from a reasonable insight into the normative validity of the principle of sustainability. For Bederna, religious education for sustainable development is therefore primarily "about ethical judgement and spirituality, resilience against what is considered normal, imagination and the courage to think differently" (p. 22).

In this lucid argument, we can observe a double normativity: The demand that religious education should follow the principle of sustainability, and the thematic demonstration that it can do so through its specific content, are both presented in a normative way-the former on the basis of normative ethics, the latter by means of normative theology. The more we agree with the position presented—which I would like to do explicitly- the more the following question comes to the fore: Is religious education-with its concrete personal,

\footnotetext{
${ }^{2}$ Both approaches possess advantages and disadvantages, but derive their plausibility from the educational context for which they were developed and in which they are applied. Consequently, the point at hand is not to evaluate both approaches against each other, but to present the conceptual and practical challenge with which both are equally confronted.
} 
contextual and structural conditions-able to meet the educational expectations and the religious hopes placed upon it as religious education for sustainable development?

Therefore, we need to perform a reality check and question what are the realistic possibilities for religious education to follow the "prophetic call for sustainable development" (Effiong 2011, p. 3)? This question refers emphatically to empirical research, which has to date been extremely scant. However, research from primarily environmental sociology and psychology has shown that religious orientations play an important role in sustainability issues (for overviews cf. Tomalin et al. 2019; Jenkins et al. 2018; Basedau et al. 2017; Ronan 2017; Sachdeva 2016; Haluza-DeLay 2014; Tucker 2006), although the connections are by no means clear. Whether religious orientations positively or negatively affect the formation of a sustainable environmental orientation depends on many personal and contextual factors, and not least, on the respective religious orientation itself (Baugh 2019; Ives and Kidwell 2019; Basedau et al. 2017; Pater and Dankelman 2009; Sherkat and Ellison 2007). Hardly any specific empirical evidence is available for this concerning young people, and despite empirical research on sustainability awareness among young people (Gifford and Nilsson 2014), the effects of religious orientations remain largely unknown. The few available studies indicate that religious orientations might positively relate to environmental awareness (Albert et al. 2019; Francis and Penny 2016; Burgert 2013). However, explicit research findings on the impact of religious education in this context are so far lacking (Kvamme 2017).

In summary: the issues addressed in this introduction are as important as they are complex and the empirical research gap is considerable. For this reason, we need to limit the present study for it at least to make a preliminary contribution to the question of whether and in what ways religious education might contribute to education for sustainable development. On the one hand, I will limit myself to problems of environmental sustainability and to students who attend secondary school in Germany and Austria. On the other hand, I will concentrate on decision-making in everyday situations that have a dilemma structure. Some research, primarily from science education, has recommended that focus should be placed on decision-making in conflictive situations (Lee et al. 2019; Garrecht et al. 2018; Gresch et al. 2017; Jho 2015; Jho et al. 2014; Steffen and Hößle 2014; Tuncay et al. 2012; Zeidler et al. 2005). The present study addresses the factors that influence such a decision and its evaluation and the impacts of religious orientations and participation in (Christian) religious education. On this basis, I will initially discuss how religious education could realistically contribute to the emerging sustainability transitions as addressed in education for sustainable development.

\section{Materials and methods}

To address the research questions in a focused manner, an interdisciplinary research team conducted a questionnaire study with 14- to 16-year-old students at a total of 19 secondary schools in Germany and Austria. The survey was conducted in two stages; first in Germany at the end of 2018 and then in Austria at the end of 2019. A comprehensive description of the research design and the survey instruments has already been published (Altmeyer and Dreesmann 2020a, b). Here, we restrict ourselves to describing some central characteristics of the sample and the instruments used, which were especially developed for the purpose of the study. The focal point of the survey was the so-called poplar dilemma, which was 
presented to the students for evaluation as a questionnaire. The conflictive situation was this:

Please imagine the following: Six months ago, a young family with two children your age bought a house in your neighbourhood and moved in. In the garden belonging to the house, is a big tree, a 50-year-old poplar. After a short time, one of the children developed a severe allergy against poplar pollen. Your new neighbours have now decided to cut down the tree. What do you think about your neighbours' decision?

Participants were invited to rate the decision to fell the poplar on a 5-point scale (from $1=$ agree to $5=$ disagree). A set of 32 arguments was then provided, each of which could be similarly evaluated by degrees of agreement or disagreement. Another section offered a small set of questions focused on concrete examples of nature and religious experience. The questionnaire also presented some questions that addressed different attitudes towards nature and biblical creation spirituality, most of which were taken from previous studies with adolescents in Germany (Sieg et al. 2018; Sammet et al. 2015; Ziebertz and Riegel 2008; Brämer 2006). In the German subsample, some knowledge questions were also asked to assess the state of reflected knowledge about biblical creation theology as it could be expected according to current school curricula of Christian religious education. Additionally, we collected basic socio-biographical and contextual data (age, gender, religious affiliation, school type, participation in religious education, and class level). For the evaluations reported in this paper, I used the following variables calculated from the mentioned item sets.

- Four evaluation categories as factor variables from the 32 dilemma arguments (ranging from 1 to 5, with $1=$ agreement): (1) ecocentrism $(\alpha=0.818, N=1052)$, summarizing 7 items that reflect emotional, moral or rational emphasis on the value of nature; (2) anthropocentrism $(\alpha=0.750, N=1006)$, consisting of 8 items that represent an orientation towards human well-being, so that the value of nature is measured by its importance for human life; (3) eco-pragmatism $(\alpha=0.700, N=1050)$, representing 7 items that deal with pragmatic alternatives to conserve the ecological status quo; and (4) religious stewardship ( $\alpha=0.744, N=1070)$, which summarized three items particularly characterised by the use of religious semantics ('God', 'creation') to express an obligation to protect nature. Because the last category is particularly relevant below, I list the items that are included in the scale in "Appendix".

- Two experience scores representing experience in nature and experience with religion $(\alpha=0.769 ; 0.811 ; N=1122)$ calculated from 17 items on a three-point scale;

- Three attitude measurements as factor variables (ranging again from 1 to 5, with $1=$ agreement): (1) eco-spirituality included nine items $(\alpha=0.713, N=1039)$, with statements that express a wide-ranging love for nature and life (cf. Sponsel $2012,2019)$. This attitude included rational and, to an even greater extent, emotional aspects. Again, the items are listed in "Appendix"; (2) biblicism $(\alpha=0.785$, $N=1054$ ), summarized three items that show a literal understanding of the Bible and especially the creation stories; (3) the final measurement refers to a single item that captured the personal importance of believing in a loving Creator God.

The research team conducted the survey in biology and religious education classes at 18 state schools in the German federal states of Rhineland-Palatinate and Hesse, mainly around the two capitals Mainz and Wiesbaden, and one school in a mid-sized town in Lower Austria belonging to the catchment area of the Austrian capital, Vienna. Fully 


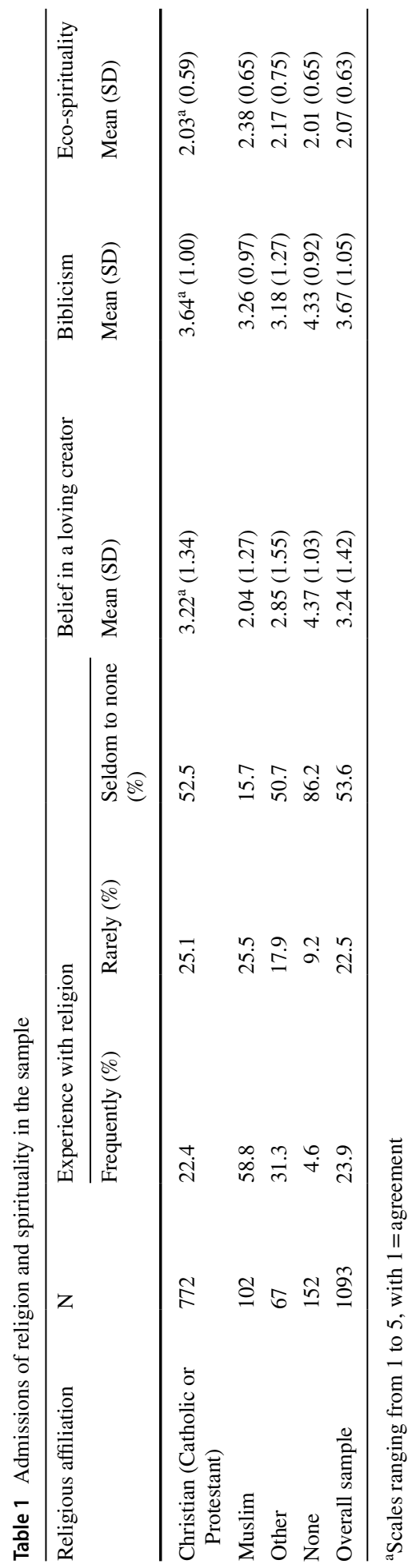


completed questionnaires were available from 1122 students, $53.2 \%$ of whom attended ninth grade and $46.8 \%$ tenth grade in secondary schools of different school types (about two-thirds were grammar schools). The participant mean age was 14.9 years $(\mathrm{SD}=0.88)$, and gender was evenly distributed $(47.3 \%$ female, $46.6 \%$ male, $6.1 \%$ not specified). Regarding religious affiliation, $70.5 \%$ of respondents were Christians (Catholic or Protestant), 9.5\% were Muslims, $6.2 \%$ belonged to other religions and $13.8 \%$ did not belong to any denomination. In total, $73.8 \%$ of students attended Christian religious education classes at school.

Experience and attitude measurements provided some interesting details on religious and spiritual orientation within the sample (Table 1). A total of 261 participants (23.9\%) reported having had experience with religion frequently, whereas the majority $(53.6 \%)$ reported little to no religious experience. The biblicism scale indicated an overall tendency towards disagreement $(\mathrm{M}=3.67, \mathrm{SD}=1.05)$. Comparably low values were found with regard to the personal significance of a belief in a Creator God. Significant differences existed, depending on religious affiliation, which were consistent with the results known from general youth studies (Albert et al. 2019). However, for the variable eco-spirituality, a high level of agreement was present, with hardly any differences in terms of religious affiliation.

\section{Results}

On average, the students in the sample evaluated the dilemma decision positively: $54.5 \%$ thought that cutting down the tree was the right thing to do, $24.6 \%$ were undecided, and only $20.7 \%$ were critical of the decision. Analyses examined the extent to which this evaluation depended on religious orientations or participation in religious education and identified hardly any correlations. The results of regression analyses did not provide a significant model (Table 2); therefore, we can assume that other reasons were responsible for the decision to the dilemma. The only exception was participation in religious education. This coincided with a lower agreement to the opinion that the tree should be felled in favour of the child's health $(\Delta M=0.26)$. More precisely, participation in religious education was

Table 2 Impact of religion on dilemma evaluation

\begin{tabular}{|c|c|}
\hline Independent variable & $\begin{array}{l}\text { Dependent variable } \\
\text { What do you think about } \\
\text { your neighbours' decision? } \\
\beta \text { (stand.) }\end{array}$ \\
\hline \multicolumn{2}{|l|}{ Religious affiliation (Christian) } \\
\hline \multicolumn{2}{|l|}{ Religious affiliation (Islam) } \\
\hline \multicolumn{2}{|l|}{ Religious affiliation (other) } \\
\hline Participation in religious education & $0.099(p=0.003)$ \\
\hline \multicolumn{2}{|l|}{ Experience with religion } \\
\hline \multicolumn{2}{|l|}{ Belief in loving Creator God } \\
\hline \multicolumn{2}{|l|}{ Biblicism } \\
\hline Model accuracy (adjusted $R^{2}$ ) & 0.006 \\
\hline Model significance & $F(7,1056)=1.948(p=0.059)$ \\
\hline
\end{tabular}


Table 3 Explanation of dilemma decision by evaluation categories

\begin{tabular}{ll}
\hline & $\begin{array}{l}\text { Dependent variable } \\
\text { Independent variable }\end{array}$ \\
& $\begin{array}{l}\text { What do you think about } \\
\text { sion? }\end{array}$ \\
& $\beta$ (stand.) \\
\hline Ecocentrism & $-0.248^{* *}$ \\
Anthropocentrism & $0.398^{* *}$ \\
Eco-pragmatism & $-0.090^{*}$ \\
Religious stewardship & -0.038 (n.s.) \\
Model accuracy (adjusted $\left.R^{2}\right)$ & 0.381 \\
Model significance & $F(4,1090)=169.013 * *$ \\
\hline
\end{tabular}

$* *$ Significant at $p<0.001, *$ significant at $p<0.05$

reflected in significantly fewer votes for full approval of the pro-child decision and significantly more students chose the middle of the scale (I am undecided) $(p<0.05)$.

However, a different picture emerged for the evaluation categories, which provided a very good model for predicting the decision in the dilemma (Table 3). Thinking in anthropocentric categories was clearly associated with agreement to cut down the tree, and ecocentrism was almost as clearly associated with the opposite decision. Eco-pragmatism also led to a more critical view of the decision against the tree, although the effect was less pronounced. Particularly relevant for our question was the finding that religious stewardship did not significantly influence the dilemma decision, which may mean that this evaluation category can justify a decision that is pro-child and against the tree, or vice versa. We could assume that this category is potentially oriented towards overcoming this dichotomy.

On the basis of these findings, I queried the variables on which preference for one of the four evaluation categories mentioned, depended. Additional regression analysis was used to test potential interdependencies. In addition to religious orientation and participation in religious education, the procedures also included the variables on nature orientation and gender. Table 4 summarizes the results and only lists significant coefficients.

For the eco-pragmatism and anthropocentrism categories, the low model accuracy indicates that other factors not examined here were decisive. For religious stewardship and ecocentrism, however, striking results were observed. Religious orientations showed a high impact on religious stewardship and no impact on ecocentrism. Christian students for whom the belief in a loving Creator is important and who have experience with religion were likely to align with religious stewardship. Attendance of religious education might reinforce this effect, whereas a literal understanding of the Bible had no influence. Instead, biblicism apparently promoted a more eco-pragmatic view. A more frequent experience of nature primarily resulted in an ecocentric evaluation. However, the variable eco-spirituality was particularly interesting, because it was the only variable that affected all evaluation categories and also consistently showed the highest effects. Eco-spirituality manifested very clearly in an ecocentric evaluation pattern, but might also reinforce eco-pragmatism and religious stewardship. However, anthropocentric values were not compatible with a spiritual attitude towards nature. In total, 171 students showed high approval values for both eco-spirituality and religious stewardship and did not express clear preferences in the dilemma, whereas the 119 students who scored highly for ecocentrism and eco-spirituality voted much more strongly in favour of the tree. 


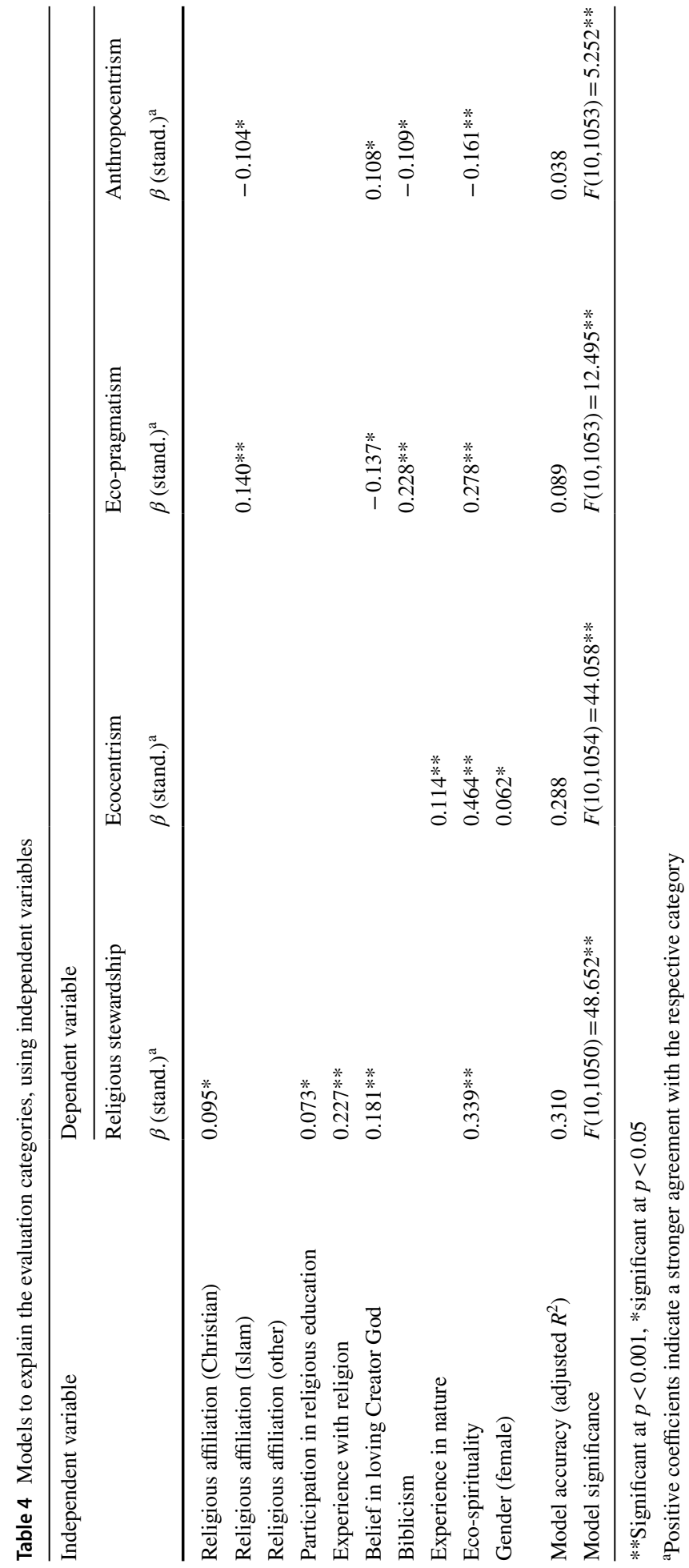


Table 5 The experience of students with religion and degree of acceptance of religious stewardship

\begin{tabular}{llccc}
\hline Experience with religion & \multicolumn{2}{l}{ Religious stewardship } & \multirow{2}{*}{ Total N (\%) } \\
\cline { 2 - 4 } & $\begin{array}{l}\text { Strong agree- } \\
\text { ment N (\%) }\end{array}$ & Agreement N (\%) & Other N (\%) & \\
\hline Frequently & $116(10.6)$ & $98(8.9)$ & $51(4.6)$ & $265(24.1)$ \\
Seldom & $65(5.9)$ & $110(10.0)$ & $72(6.6)$ & $247(22.5)$ \\
Little to none & $92(8.4)$ & $209(19.0)$ & $286(26.0)$ & $587(53.4)$ \\
Total & $273(24.8)$ & $417(37.9)$ & $409(37.2)$ & $1099(100.0)$ \\
\hline
\end{tabular}

One assumption could be that participation in religious education affects students' religious knowledge; hence, elaborate knowledge of biblical creation theology conveyed through religious education might potentially positively affect the category of religious stewardship. Data concerning students' knowledge of biblical creation theology were available for the German subsample $(N=870)$, and regression analyses revealed that the variable 'participation in religious education' can be replaced by 'religious knowledge' and the same correlations are upheld: knowledge about biblical theology of creation influenced agreement with the category of religious stewardship in combination with the factors mentioned above $[\beta$ (stand. $)=0.092, p=0.017]$.

The results allow the following conclusion to be drawn: although religious orientations and participation in religious education (reflected in knowledge on the theology of creation) clearly do not influence ecocentric attitudes and only weakly impact ecopragmatism and anthropocentrism, they clearly affect religious stewardship. However, religious stewardship is also most strongly influenced by an eco-spiritual attitude; in other words, religious stewardship is related to religion, and also to spirituality.

Further analyses showed that these two areas were not identical at all. Even a basic descriptive statistic showed that more than $60 \%$ of all students $(N=690)$ agreed with the concept of religious stewardship, and one-quarter of all participants strongly agreed $(N=273)$. However, $43.6 \%$ of these supporters $(N=301)$ stated that they had rarely or never had any experience with religion (Table 5).

The study examined in more detail the particularly interesting group of 92 students (8.4\%) who strongly agreed with the category of religious stewardship, but had had little or no contact with religion. Table 6 shows how the results of these students differed significantly from those of the others.

These students tended to be neutral in their approach to the dilemma, but at the same time were strongly in favour of the ecocentric perspective. This is a striking difference compared with the overall sample, because ecocentrism was generally associated with a decision in favour of the tree. We could imagine that for these students, the ecocentric perspective also includes the well-being of the child to a greater extent. In terms of religious orientations, these students were opposed to belief in the Creator, a literal understanding of the Bible, and religious anthropocentrism; they also felt that concepts of God should be reconsidered in the light of scientific knowledge. On the other hand, they revealed a special connection with nature: They acknowledged nature's own laws, recognised a duty to protect nature, and linked these ecological questions with the ethical concept of conscience. Although experience in Nature did not affect the results from these students, they scored particularly high values in eco-spirituality. From these 


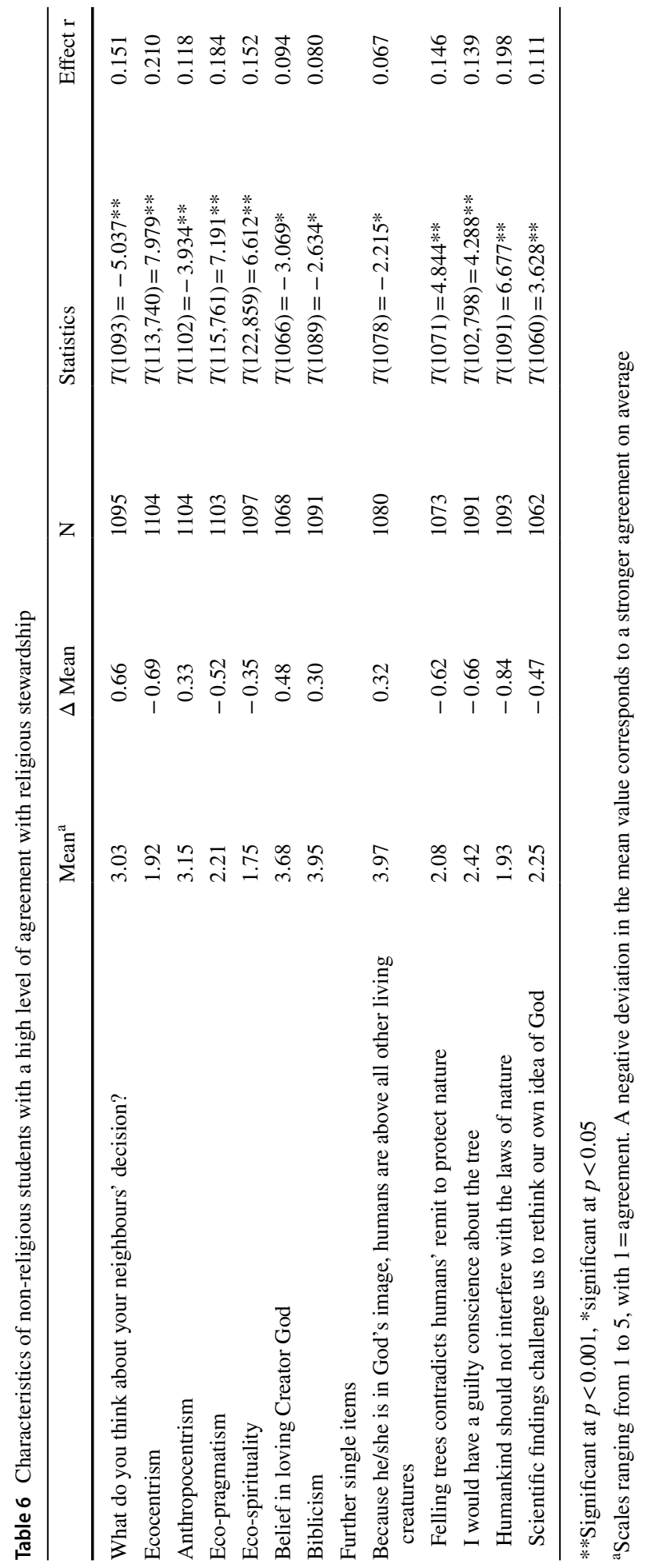


results, we can conclude that these students reinterpreted the concept of religious stewardship individually: they agreed with religious semantics, but placed themselves outside of the explicit (Christian) religion. For them, religious stewardship represented an expression of ecological spirituality, instead of a (traditional) religious orientation. Nevertheless, they shared with the more religious students the position that religious stewardship was a preferable response to the ecological decision-making situations in question.

\section{Discussion}

The goals of education for sustainable development place an obligation on the whole school and thus, also on religious education. Due to its specific perspective within the school, religious education is confronted with the task of developing a very specific contribution to this key issue in interaction with other subjects. Ecological problems represent an important aspect of the educational and developmental goals addressed in this context. This study therefore focused on the potential contribution of religious education to ecological sustainability. In this still very broad area, the study focused on a sustainability dilemma from the everyday life of German and Austrian young people, and confronted students aged 14-16 years with the so-called poplar dilemma. Students were challenged to evaluate the decision of a neighbouring family that had decided to cut down a 50-year-old poplar tree that had caused a serious allergy in one of their children shortly after the family moved into the house. This everyday example raised the question concerning which factors play a role in the evaluation of this decision and whether religious orientations and participation in (Christian) religious education are significant in this context. On this basis, I would now like to ask whether religious education could contribute to educationally fostered sustainability transitions and to explore the nature of this contribution.

First, the study identified no direct influence of religious orientation on the decision in the dilemma. This corresponds with the finding of previous research that religion does not play a strong behavioural role for the vast majority of Central European young people in questions of everyday value orientation (overview: Riegel 2015) similar to the dilemma situation under study here. Here, other values play a much greater role-as demonstrated by the poplar dilemma instrument. The evaluation categories of ecocentrism, eco-pragmatism and anthropocentrism, which have also been discussed as being important influencing factors in other studies (Affifi 2020; Kopnina and Cocis 2017; Cocks and Simpson 2015; Kortenkamp and Moore 2001), had large and partly opposing influences on the decision. A particularly interesting fourth category was a so-called religious stewardship pattern (Graham 2020; Martin 2015; Welchman 2012). This category represented the idea that humans are obliged to assume responsibility towards nature, and this is articulated by religious semantics (concepts such as creation or God). It is particularly relevant that religious stewardship not only received the highest ratings in our sample, but it also moderated in the interplay with the other categories: religious stewardship could be used to justify both the protection of the child and of the tree, so that finally, a neutral attitude towards the dilemma decision was often adopted. This finding is surprisingly congruent with more recent theological positions, which also clearly advocate that the biblical story of creation certainly does not imply a right of human beings to dominate, but instead, "calls for a caring responsibility for other creatures that reflects but does not usurp God's own care for his creation" (Bauckham 2010, p. 34; cf. Conradie 2010, pp. 305-307; even more strictly ecocentric: Habel and Wurst 2000). One conclusion from this is that through a particular focus on the idea 
of religious stewardship, religious education could provide a good opportunity to work with students constructively (Grelle 2018). However, to expect religious education to offer far-reaching opportunities to change sustainability-related attitudes beyond "environmental sensitivity" (Effiong 2011, p. 124) must be regarded as rather unrealistic.

This thesis was substantiated and refined by further findings in this study, which showed that religious stewardship was positively influenced by religious orientations and participation in religious education, although this was not the case for ecocentrism. Few meaningful correlations were observed for eco-pragmatism and anthropocentrism, which were mainly influenced by other factors. Collectively, we can conclude that religious students can be positively encouraged towards the idea of religious stewardship by participation in religious education, whereas ecocentric attitudes tend to be unaffected by religious education. This finding is consistent with that of other research, which has identified an increasingly responsible, ecological but not strictly ecocentric orientation within Christianity under the label of a so-called greening of religion hypothesis (Baugh 2019; Taylor et al. 2016; Taylor 2011). With regard to Christian religious education, reflected knowledge of biblical creation theology seems to be important here, which additionally counteracts biblicism.

The findings extend even further, however, because the concept of religious stewardship was not limited to religious students among the young people in this study: by contrast, for a surprisingly high proportion of students (27.4\%), religious stewardship was also compatible with a categorically non-religious attitude. Almost $9 \%$ of the students even felt that belief in a Creator God was completely unimportant to them and that conceptions of God had to be revised in the light of scientific findings, but they mainly agreed with the category of religious stewardship. Therefore, we can conclude that these students would also benefit from the religious education perspective. A precondition for this would be to offer educational opportunities for them to enter into dialogue with the more religiously oriented students, or to collectively assume ecological responsibility under the shared perspective of religious stewardship in the school community as "engaged practitioners of change" (Sandberg 2020, p. 417). A precondition for exchange and understanding might again be a reflected knowledge of Creation Theology, which also assumes and elaborates critical perspectives (Horrell and Davis 2014; O'Brien 2014), including an anthropocentric bias inherent to the stewardship metaphor (Graham 2020; Martin 2015).

The tendency of individuals to orientate towards the category of religious stewardship was thus not only dependent on religious orientations, and the study identified another, more influential factor: a so-called eco-spirituality (Sponsel 2012, 2019). This consisted of a fascination for and love of nature, the idea of a fundamental goodness of nature, the willingness to help nature as much as possible, or the idea of a soul in nature. Eco-spirituality played a central role in the emergence of both ecocentrism and religious stewardship. In connection with religious stewardship, eco-spirituality led to a relatively open attitude towards the decision in the dilemma, whereas together with ecocentrism, it led to a commitment to preserve the tree. This leads us to conclude that for religious education, a combination of the concepts of religious stewardship with a spiritual approach to nature (Tomlinson 2019; Martin 2015; Ayres 2014; Gottlieb 2006) might "foster awareness, nurture conversation, and encourage the development of a vision of ecological development" (Effiong 2011, pp. 4-5). At the same time, even the biblical tradition, justifiably, is quite critical of idealising nature (Bauckham 2010, pp. 109-115). This resonates with current dilemmas, which consistently demonstrate that the notion of 'innocent nature' is an illusion, sometimes even an ideology.

Even if the above-mentioned findings only provide preliminary empirical evidence that urgently requires further research-especially through intervention studies on the actual impact of religious education, we can already make a well-founded statement: religious education offers the potential to specifically contribute to the goals of ecological education 
for sustainable development. For example, it can support religiously oriented students to develop an attitude of religious stewardship, but non-religious students are also amenable to this orientation. This and other studies have shown that questions of sustainable development and climate change are increasingly perceived as religious or spiritual issues-even beyond explicit religious orientations (Altmeyer and Dreesmann 2020b; Jenkins et al. 2018; Berry 2013; Sponsel 2012; Gottlieb 2006). Because of this, religious education could raise the question "how our ecological and moral imaginations might be stimulated through an encounter with these alternative [i.e. religious] perspectives on being in the world" (Grelle 2018, p. 195), and could sensitise students to take collective and personal responsibility. Theoretically, it could develop a specific translation competence with the aim of facilitating understanding of the religious/spiritual dimension in sustainability, on the basis of differing religious orientations.

To explain what this 'translation competence' represents, I would like to take the position of the German sociologist Nassehi (2017), who has profiled the concept as fundamentally important in view of current societal challenges. For Nassehi, the central characteristic of contemporary modern societies is their complexity: "In all areas of society, a wide variety of different authorities are now having their say at the same time. [...] A complex reciprocity of non-coordinated voices emerges, which must be related to one another." (p. 16, own translations) The fundamental problem of complexity is that everything always has a "multiple meaning" (p. 65) due to different logics, which are unconnected and nevertheless claim equal importance, which is why it is difficult to reach a consensus even on broadly acknowledged important goals such as sustainable development. The only solution for Nassehi is to deal with this complexity by developing what he calls a translation competence. When politicians, climate researchers, economists and church representatives discuss the topic of climate change on a talk show for example, it is unhelpful to assume that a common denominator could be found that would integrate the diverse standpoints and underlying world views. Communication would fail if a mandatory consensual agreement had to be reached in which the various normativities were made ultimately compatible. Instead, the participants in the talk show must continue to communicate and recount their different perspectives to each other. By analogy to society as a whole, what is centrally important is the "management of interruptions" (p. 199). According to Nassehi, the constantly open process of understanding must never come to a standstill. It is the ability to translate that is paramount, i.e., the ability to communicate with each other despite different normatively grounded languages through a decisive management of interruptions. The metaphor of translation thus emphasises that we must abandon the idea of being able to harmonise the heterogeneity of beliefs and world views, but still need to work onto a common basis for communicating and acting collaboratively.

On this basis, we could also profile the potential contribution of religious education to sustainable development in the context of other school subjects. The contribution of religious education would then rest less on introducing further normativity based on religion, but would rather help to translate different normativities in view of the ecological crisis, which is recognised as a religious challenge. Translation competence in religious education would involve perceiving one's own fundamental orientations with regard to everyday ecological decision-making, articulating them, and engaging in dialogue with the frequently differing orientations of others. During religious education, communicative interruptions could then be addressed and a new common language sought, whereby religious and world view orientations would become explicitly thematic. A good starting point for this could be the metaphor of religious stewardship. In an ideal case, dialogue on fundamental orientations in the search for a language that bridges communicative interruptions could also help to initiate concrete commitments to personal and joint responsibility. To resume the example of the poplar dilemma in religious education, we would then not only 
ask what values are competing, but how the conflict challenges us to reflect and communicate anew on what it means to be truly human and deeply religious in relation to nature.

Finally, a comment on the limitations of this study. These exist and are manifold, and clearly refer to the question to what extent generalisations are possible, based on the small and locally limited sample. Alternatively, we could criticise the poplar dilemma in terms of an ethnocentric or middle-class bias (Nielsen et al. 2017; Henrich et al. 2010). Another important point is that the influence of religious education on ecological sustainability was investigated without concrete questions being asked about ecological sustainability, and without investigating what had been previously taught in religious education. Above all, solid intervention studies are needed to examine the real impact of educational programmes in religious education for sustainable development. When I became aware of all these limitations, I decided to qualify the title with the small word 'initial'. This was to express the hope that the hypotheses and questions raised by the research presented here will inspire as many people as possible to continue working on this global key question through further research and committed teaching practice.

Acknowledgements The author would like to thank all students and teachers involved in this study for their cooperation. I am grateful to Professor Dr. Daniel Dreesmann for his great cooperation on this project, to Astrid Hesse and Maren Hornberger for contributing to early versions of the questionnaire as well as to Simon Ferel for supporting initial data analyses. Finally, the excellent proofreading by Dr. John Chandler is greatly acknowledged.

Funding Open Access funding enabled and organized by Projekt DEAL.

\section{Compliance with ethical standards}

\section{Conflict of interest None.}

Open Access This article is licensed under a Creative Commons Attribution 4.0 International License, which permits use, sharing, adaptation, distribution and reproduction in any medium or format, as long as you give appropriate credit to the original author(s) and the source, provide a link to the Creative Commons licence, and indicate if changes were made. The images or other third party material in this article are included in the article's Creative Commons licence, unless indicated otherwise in a credit line to the material. If material is not included in the article's Creative Commons licence and your intended use is not permitted by statutory regulation or exceeds the permitted use, you will need to obtain permission directly from the copyright holder. To view a copy of this licence, visit http://creativecommons.org/licenses/by/4.0/.

\section{Appendix}

See Tables 7 and 8 .

Table 7 Religious stewardship

Item

Corrected item-

scale correla-

tion

All life is God's creation and has an intrinsic value that must be respected

0.655

Humans have received the task from God to deal responsibly with animals and the rest of 0.624 nature and to preserve the diversity of the world

I think that humankind must actively work to preserve creation

0.450 
Table 8 Eco-spirituality

Item

Corrected item-

scale correlation

I want to help nature as best I can

Why do you think nature should be protected? Out of love for nature $\quad 0.485$

$\begin{array}{ll}\text { Insects are useful creatures } & 0.456\end{array}$

Why do you think nature should be protected? To preserve the diversity of species $\quad 0.422$

$\begin{array}{ll}\text { If I find an insect in my room, I put it outside } & 0.409\end{array}$

$\begin{array}{ll}\text { I find insects fascinating } & 0.405\end{array}$

$\begin{array}{ll}\text { It is better for nature if I don't travel so far away for holidays } & 0.329\end{array}$

$\begin{array}{ll}\text { What is natural is good } & 0.243\end{array}$

$\begin{array}{lr}\text { Plants have a soul } & 0.290\end{array}$

\section{References}

Affifi, R. (2020). Anthropocentrism's fluid binary. Environmental Education Research, 16(2), 1-18.

Albert, M., Hurrelmann, K., \& Quenzel, G. (2019). Jugend 2019: Eine Generation meldet sich zu Wort. Shell-Jugendstudie (Vol. 18). Weinheim: Beltz.

Altmeyer, S., \& Dreesmann, D. (2020a). The tree was there first - using an everyday ecological dilemma to explore the personal orientations of secondary school students in environmental decision-making. Environmental Education Research, 1-22. https://doi.org/10.1080/13504622.2020.1853062

Altmeyer, S., \& Dreesmann, D. (2020b). The importance of religion for the evaluation of everyday ecological decisions by German adolescents: A case study with students in biology and religious education classes. Worldviews, 24(3), 285-307.

Ayres, J. R. (2014). Learning on the ground: ecology, engagement, and embodiment. Teaching Theology and Religion, 17(3), 203-216.

Ayres, J. R. (2017). Cultivating the "unquiet heart": Ecology, education, and Christian faith. Theology Today, 74(1), 57-65.

Basedau, M., Gobien, S., \& Prediger, S. (2017). The ambivalent role of religion for sustainable development: A review of the empirical evidence. GIGA Working Papers No. 297. Hamburg. Retrieved September 11, 2020, from http://www.giga-hamburg.de/workingpapers.

Bauckham, R. (2010). Bible and ecology: Rediscovering the community of creation. Sarum theological lectures series. Waco, TX: Baylor University Press.

Baugh, A. J. (2019). Explicit and embedded environmentalism: Challenging normativities in the greening of religion. Worldviews, 23(2), 93-112.

Bederna, K. (2020). Every day for future: Theologie und religiöse Bildung für nachhaltige Entwicklung (2nd ed.). Ostfildern: Grünewald.

Berry, E. (2013). Religious environmentalism and environmental religion in America. Religion Compass, $10(7), 454-466$.

Bouma-Prediger, S. (2016). What kind of person would do something like that? A Christian ecological virtue ethic. International Journal of Christianity and Education, 20(1), 20-31.

Brämer, R. (2006). Natur obskur: Wie Jugendliche heute Natur erfahren. München: Oekom-Verl.

Bratton, S. P. (1990). Teaching environmental ethics from a theological perspective. Religious Education, $85(1), 25-33$.

Burgert, S. (2013). With green in mind: Formative influences on ecological mindedness. Electronic Theses and Dissertations No. 101. Retrieved May 28, 2020, from https://digitalcommons.du.edu/etd/101.

Chamberlain, G. L. (2000). Ecology and religious education. Religious Education, 95(2), 134-150.

Cocks, S., \& Simpson, S. (2015). Anthropocentric and ecocentric: An application of environmental philosophy to outdoor recreation and environmental education. Journal of Experiential Education, 38(3), 216-227.

Conradie, E. M. (2010). What on earth is an ecological hermeneutics? Some broad parameters. In D. G. Horrell, C. Hunt, C. Southgate, \& F. Stavrakopoulou (Eds.), Ecological hermeneutics. Biblical, historical, and theological perspectives (pp. 295-313). London: T. and T. Clark.

Dunn, S. (1990). Ecology, ethics, and the religious educator. Religious Education, 85(1), 34-41. 
Effiong, N. B. (2011). Religious education for environmental awareness: A new approach for fostering sustainable. Dissertation, Fordham University, New York. Retrieved September 17, 2020, from https:// research.library.fordham.edu/dissertations/AAI3446880/.

Fleischer, B. J., \& DeMoor, E. (2015). Hope for environmental action. Religious Education, 110(3), 274-288.

Francis (2015). Encyclical Letter Laudato Si’ on care for our common home. Rome.

Francis, L. J., \& Penny, G. (2016). The personal and social significance of diverse religious affiliation in multi-faith London. In E. Arweck (Ed.), AHRC/ESRC religion and society series. Young people's attitudes to religious diversity (pp. 222-241). London: Taylor and Francis.

Garrecht, C., Bruckermann, T., \& Harms, U. (2018). Students' decision-making in education for sustainability-related extracurricular activities-A systematic review of empirical studies. Sustainability, 10(11), 3876.

Gifford, R., \& Nilsson, A. (2014). Personal and social factors that influence pro-environmental concern and behaviour: A review. International Journal of Psychology, 49(3), 141-157.

Gottlieb, R. S. (2006). A greener faith: Religious environmentalism and our planet's future. Oxford: Oxford University Press.

Graham, M. (2020). Thomas Berry and the reshaping of Catholic environmentalism. Worldviews, 24(2), $156-183$.

Grelle, B. (2018). Worldviews, ethics, and ecology: 'Sustainability' as a context for religious education. In J. Astley, L. J. Francis, \& D. W. Lankshear (Eds.), Religion, education and values. Values, human rights and religious education. Contested grounds (Vol. 14, pp. 189-206). Oxford: Peter Lang.

Gresch, H., Hasselhorn, M., \& Bögeholz, S. (2017). Enhancing decision-making in STSE education by inducing reflection and self-regulated learning. Research in Science Education, 47(1), 95-118.

Habel, N. C., \& Wurst, S. (Eds.). (2000). Earth Bible. The earth story in genesis (Vol. 2). London: Continuum International Publishing.

Haluza-DeLay, R. (2014). Religion and climate change: Varieties in viewpoints and practices. WIREs Climate Change, 5(2), 261-279.

Henrich, J., Heine, S. J., \& Norenzayan, A. (2010). The weirdest people in the world? The Behavioral and Brain Sciences, 33(2-3), 61-135.

Hill, B. R. (1990). Creation education: An overview of contemporary theological education. Religious Education, 85(3), 382-400.

Horrell, D. G., \& Davis, A. (2014). Engaging the Bible in GCSE and A level Religious Studies: Environmental stewardship as a test case. British Journal of Religious Education, 36(1), 72-87.

Hoven, M. (2015). Teaching creation: Ancient belief meets modern science. Journal of Religious Education, 63(1), 1-12.

Ives, C. D., \& Kidwell, J. (2019). Religion and social values for sustainability. Sustainability Science, 14(5), 1355-1362.

Jenkins, W., Berry, E., \& Kreider, L. B. (2018). Religion and climate change. Annual Review of Environment and Resources, 43(1), 85-108.

Jho, H. (2015). A literature review of studies on decision-making in socio-scientific issues. Journal of the Korean Association for Science Education, 35(5), 791-804.

Jho, H., Yoon, H.-G., \& Kim, M. (2014). The relationship of science knowledge, attitude and decision making on socio-scientific issues: The case study of students' debates on a nuclear power plant in Korea. Science and Education, 23(5), 1131-1151.

Kopnina, H., \& Cocis, A. (2017). Testing Ecocentric and Anthropocentric Attitudes toward the Sustainable Development (EAATSD) scale with Bachelor students. European Journal of Sociology and Anthropology, 2(1), 1-16.

Kortenkamp, K. V., \& Moore, C. F. (2001). Ecocentrism and anthropocentrism: Moral reasoning about ecological commons dilemmas. Journal of Environmental Psychology, 21(3), 261-272.

Kvamme, O. A. (2017). The significance of context: Moral education and religious education facing the challenge of sustainability. Discourse and Communication for Sustainable Education, 8(2), 24-37.

Lee, Y. C., Grace, M., Rietdijk, W., \& Lui, Y. C. (2019). A cross-cultural, cross-age, and cross-gender study of Hong Kong and UK secondary students' decision making about a biological conservation issue. International Journal of Science Education, 41(18), 2696-2715.

Martin, M. K. (2015). The cry of earth and conflict with human cultures: A reflection for Christian religious educators. Journal of Religious Education, 63(1), 25-36.

Nassehi, A. (2017). Die letzte Stunde der Wahrheit: Kritik der komplexitätsvergessenen Vernunft. kursbuch-edition. Hamburg: Murmann. 
Nielsen, M., Haun, D., Kärtner, J., \& Legare, C. H. (2017). The persistent sampling bias in developmental psychology: A call to action. Journal of Experimental Child Psychology, 162, 31-38.

O'Brien, K. J. (2014). Balancing critique and commitment: A synthetic approach to teaching religion and the environment. Teaching Theology and Religion, 17(3), 189-202.

Pater, C. D., \& Dankelman, I. (Eds.). (2009). Nijmegen studies in development and cultural change. Religion and sustainable development: Opportunities and challenges for higher education (Vol. 46). Berlin: Lit.

Price, E. B. (2008). Christian nurture and the new cosmology. Religious Education, 103(1), 84-101.

Riegel, U. (2015). Ethik in den Köpfen Jugendlicher und im Religionsunterricht: Eine empirische Bilanz. In R. Englert, H. Kohler-Spiegel, E. Naurath, B. Schröder, \& F. Schweitzer (Eds.), Ethisches Lernen. Jahrbuch der Religionspädagogik (Vol. 31, pp. 98-107). Neukirchen-Vluyn: Neukirchener.

Ronan, M. (2017). Religion and the environment: Twenty-first century American Evangelicalism and the Anthropocene. Humanities, 6(4), 92.

Sachdeva, S. (2016). Religious identity, beliefs, and views about climate change. Oxford research encyclopedias of climate science. Retrieved September 24, 2019, from https://oxfordre.com/climatescience/.

Sammet, R., Andres, H., \& Dreesmann, D. (2015). Human-insect relationships: An ANTless story? Children's, adolescents', and young adults' ways of characterizing social insects. Anthrozoös, 28(2), 247-261.

Sandberg, K. (2020). Teaching for social impact: Integrating generational goals and concerns into religious education. Journal of Religious Education, 68(3), 417-434.

Sherkat, D. E., \& Ellison, C. G. (2007). Structuring the religion-environment connection: Identifying religious influences on environmental concern and activism. Journal for the Scientific Study of Religion, 46(1), 71-85.

Sieg, A.-K., Teibtner, R., \& Dreesmann, D. (2018). Don't know much about bumblebees? A study about secondary school students' knowledge and attitude shows educational demand. Insects, 9(2), 40.

Sponsel, L. E. (2012). Spiritual ecology: A quiet revolution. Santa Barbara, CA: Praeger.

Sponsel, L. E. (2019). Ecology and spirituality. Oxford research encyclopedia of religion. Retrieved May 24, 2020, from https://oxfordre.com/religion/view/https://doi.org/10.1093/acrefore/9780199340 378.001.0001/acrefore-9780199340378-e-95.

Steffen, B., \& Hößle, C. (2014). Decision-making competence in biology education: Implementation into German curricula in relation to international approaches. EURASIA Journal of Mathematics, Science and Technology Education, 10(4), 343-355.

Taylor, B. R. (2011). Editor's introduction: Toward a robust scientific investigation of the 'religion' variable in the quest for sustainability. Journal for the Study of Religion, Nature and Culture, 5(3), 253-262.

Taylor, B. R., van Wieren, G., \& Zaleha, B. D. (2016). Lynn White Jr. and the greening-of-religion hypothesis. Conservation Biology, 30(5), 1000-1009.

Tomalin, E., Haustein, J., \& Kidy, S. (2019). Religion and the sustainable development goals. The Review of Faith and International Affairs, 17(2), 102-118.

Tomlinson, J. (2019). Ecological religious education: New possibilities for educational practice. Journal of Religious Education, 67(3), 185-202.

Tucker, M. E. (2006). Religion and ecology: Survey of the field. In R. S. Gottlieb (Ed.), The Oxford handbook of religion and ecology (pp. 398-418). Oxford: Oxford University Press.

Tuncay, B., Yılmaz-Tüzün, Ö., \& Teksoz, G. T. (2012). Moral reasoning patterns and influential factors in the context of environmental problems. Environmental Education Research, 18(4), 485-505.

UNESCO Section for Education for Sustainable Development. (2006). Framework for the UN DESD international implementation scheme. Retrieved September 16, 2020, from https://unesdoc.unesco.org/ ark:/48223/pf0000148650.

United Nations. (2015). Transforming our world: The 2030 Agenda for Sustainable Development. Retrieved September 16, 2020, from https://sustainabledevelopment.un.org/post2015/transformingourworld/ publication.

United Nations Conference on Environment and Development (UNCED). (1992). Agenda 21. Retrieved September 16, 2020, from https://sustainabledevelopment.un.org/content/documents/Agenda21.pdf.

Welchman, J. (2012). A defence of environmental stewardship. Environmental Values, 21(3), 297-316.

Zeidler, D. L., Sadler, T. D., Simmons, M. L., \& Howes, E. V. (2005). Beyond STS: A research-based framework for socioscientific issues education. Science Education, 89(3), 357-377.

Ziebertz, H.-G., \& Riegel, U. (2008). Letzte Sicherheiten: Eine empirische Untersuchung zu Weltbildern Jugendlicher. Religionspädagogik in pluraler Gesellschaft (Vol. 11). Gütersloh, Freiburg: Kaiser, Herder.

Publisher's Note Springer Nature remains neutral with regard to jurisdictional claims in published maps and institutional affiliations. 